\title{
DOI: 10.7596/taksad.v1i3.51
}

\section{Eğitim Seviyesindeki Yükselmenin Geleneksel Aile Anlayışının Değişimine Etkisi: Karabük Üniversitesi Örneği}

\author{
Sinan Yılmaz
}

\section{Özet}

Günümüzde aile ile ilgili yeni yaklaşımlar ortaya çıkmış ve geleneksel aile anlayışları değişmeye başlamıştır. Evlilik yaşının yükselmesi, boşanmaların artması, nikâhsız birlikte yaşama anlayışının yaygınlaşmaya başlaması, hanehalkı sayısının küçülmesi, çocuk sayısının azalması vb. yeni yaklaşım ve anlayışlar, sıradan bir insanın bile gözlemleyebileceği ölçüde yaygınlaşmıştır. Aile ile ilgili yeni anlayışların ortaya çıkmasını tetikleyen elbette pek çok neden vardır. $\mathrm{Bu}$ araştırmada, aile ile ilgili bu yeni anlayışların ortaya çıkmasında eğitimin rolünün ne olduğu araştırılmaktadır.

Araştırmada, aile anlayışında meydana gelen değişmelerle ilgili olarak TÜİK verilerinden yararlanıldığı gibi üniversite öğrencileri üzerinde yapmış olduğumuz bir araştırmanın sonuçlarına da yer verilmiştir. İstatistiksel veriler eğitim seviyesinin düşük olduğu dönemlerle karşılaştırılmış, böylece eğitim seviyesindeki yükselmenin nasıl bir değişim ve dönüşüme neden olduğu tespit edilmeye çalışılmıştır. Özellikle ikinci dünya savaşı sonrasında aile ile ilgili olarak Avrupa ve Amerika'da yaşanan gelişmeler de incelenmiş ve Türk ailesindeki gelişmelerle karşılaştırılarak benzer dönüşümlerin yaşanıp yaşanmayacağı tartışılmıştır.

Anahtar Kelimeler: Aile, Türk Ailesi, Geleneksel aile, Yeni aile anlayışları, Eğitim ve aile.

\section{The Effect of Increasing Education Level on Changes in Traditional Family Patterns: The Case of Karabuk University}

\section{Abstract}

Today, new approaches about the family have emerged, and traditional family patterns have started to change. The increase of marriage age, the increase in the number of divorces, the tendency for cohabitation, the decrease in the number of family members and the decline in the number of offspring have become so wide-spread that these changes could be easily 
observed even by ordinary people. There are, of course, a lot of reasons that stimulate these new approaches about the family, yet this study focuses upon the role of education concerning the emergence of these new concepts about the family.

In the study, the data taken from TUIK, as well as the results of a survey about the changes in the family patterns carried out on the university students are used. The statistical data are compared with the data of the previous periods in which the level of education was low. Additionally, the study examines how the increase in the level of education has brought about transformation in the traditional family patterns. Moreover, the transformations of family patterns in Europe and America, particularly after the Second World War, are studied, and these transformations are compared with the similar changes in the Turkish family patterns. The study also discusses whether the same transformations could be seen in Turkish family.

Keywords: Family, Turkish Family, Traditional Family, New Family Concepts, Education and Family

\section{Effet de l'élévation du niveau/grade d'études au changement de la conception de la famille traditionnelle : Le Cas de l'Université de Karabük}

\section{Résumé}

Aujourd'hui, de nouvelles approches ont vu le jour sur la famille et les conceptions de la famille traditionnelle ont commencé à changer. L'augmentation de l'âge du mariage, le nombre croissant de divorces, de personnes vivant en couple sans contrat de mariage, la diminution du nombre d'habitants au sein d'un ménage, la réduction du nombre d'enfants etc... sont des événements que l'on peut observer de plus en plus. Il existe bien sûr de nombreuses raisons qui déclenchent l'émergence de ces nouvelles conceptions au sujet de la famille. Dans cette étude, nous avons étudié le rôle de l'éducation dans l'émergence de ces nouvelles conceptions de la famille moderne.

Dans cette étude, en ce qui concerne les changements relatifs à la conception familiale nous avons utilisé les données de TÜIKK et aussi celles de notre recherche portant sur les étudiants universitaires. Les données statistiques sont comparées avec les données où le niveau d'éducation est bas dans le but de déterminer comment l'élévation du niveau d'études suscite un changement et une transformation en ce qui concerne la famille. Plus particulièrement, nous avons aussi examiné l' évolutions de la famille en Europe et aux EtatsUnis après la deuxième guerre mondiale et nous avons fait des comparaisons avec l'évolution de la famille Turque pour voir s'il existe des changements et transformations similaires.

Mots-clés : Famille, Famille turque, Famille traditionnelle, Nouvelles conception sur la famille, Education et famille. 


$$
\begin{aligned}
& \text { في يومنا الحاضر ظهرت أساليب جديدة حول الأسرة و بدأت مفاهيم "الأسرة التقليدية" تتغير . ارتفاع سن الزواج وزيادة } \\
& \text { الطلاق، وانتشار مفهوم الاختلاط بين الشباب والشابات بدون نكاح، وتقليل عدد أفراد الأسرة، وتقليل عدد الأطفال في الأسرة، } \\
& \text { وغير ذلك من المفاهيم الجديدة؛ قد شاعت في البحتمع بقدر حتى يترصدها أي إنسان عادي. لا شك أن هناك أسباب عديدة } \\
& \text { في تحريك ظهور مفاهيم جديدة تتعلق بالأسرة. في هذه الدراسة، تم البحث عن مدى دور التعليم في ظهور هذه المفاهيم الجديدة }
\end{aligned}
$$

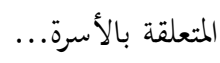

$$
\begin{aligned}
& \text { في الدراسة؛ كما تمت الاستفادة من معطيات مؤسسة إحصائيات تركيا، تترق إليه الباحث إلى نتائج البحث الذي قمنا } \\
& \text { بتطبيقه على طلاب الجامعة أيضًا. و وتمت مقارنة البيانات الإحصائية الجديدة بفترات كان فيها مستوى التعليم منخفضًا؛ لذلك } \\
& \text { حاول الباحث تحديد مدى تأثير مستوى التعليم المرتفع على سبب التغيّر و التحوّل الإجتماعي. ولاسيما، التطوّرات التي شاهدت } \\
& \text { أوروبا وأمريكا إثر الحرب العالمية الثانية حول الأسرة؛ تمت دراستها ومقارنتها بينها وبين التطوّرات التي شاهدةا الأسرة التركية و } \\
& \text { نوقشت؛ هل ستعيش نفس المراحل أم لا؟ } \\
& \text { كلمات البحث : } \\
& \text { الأسرة ، الأسرة التركية ، الأسرة التقليدية ، مفاهيم أسرية جديدة، التعليم و الأسرة.... }
\end{aligned}
$$

\section{Giriş}

Aile denince akla ilk gelen şey değişim değil sürekliliktir. İnsanoğlunun var olduğu ilk günden günümüze kadar en az değişime uğrayan sosyal kurumlardan birisi ailedir. Aile ile ilgili evrimci yaklaşımda bulunanlar olmuşsa da bu yaklaşımlar antropolojik araştırmalar neticesinde geçerliliklerini yitirmişlerdir (Yılmaz, 2008). Ailenin bu yönü nedeniyle sosyolojide aile ile ilgili olarak işlevselci/fonksiyonalist yaklaşım her zaman ön planda olmuştur (Yilmaz, 2010).

Antropolojik veriler incelendiğinde aile ile ilgili olarak, klan ailesi, pederşahi aile, maderşahi aile, pederi aile, polijini, poliandri gibi kavramlardan bahsedildiğini görmekteyiz (Haviland ve diğerleri, 2008). 
Günümüzde ise aile ile ilgili yeni kavram ve yaklaşımların ortaya çıktığını ve ailenin tarihte hiç olmadığı kadar farklı şekillerde karşımıza çıktığını görmekteyiz.

Günümüzde ortaya çıkan aile modellerinin benzerlerini geçmiş toplumlarda bulmak mümkündür. Ancak geçmişte benzerlerini bulabileceğimiz bu modellerin, günümüzdeki şekliyle kurumsallaşmış uygulamalar olduğunu söylemek zordur.

Aile ile ilgili bu yeni yönelimlerin altında yatan sebep acaba nedir? Modernizm midir? Postmodern yaklaşımlar mıdır? Ya da bunları ortaya çıkaran sanayileşme, kentleşme, sekülerleşme, eğitim seviyesinin yükselmesi ve bireyselleşme gibi unsurlar mıdır? $\mathrm{Bu}$ saydığımız etkenlerden her birinin ailenin değişimine ne kadar etki ettiği ayrı ayrı incelenebilir. Örneğin sanayileşme kadınların işgücüne katılımını artırmış, kentleşme mekanik ilişkileri organik ilişkilere dönüştürmüş, sekülerleşme muhafazakâr yaklaşımların terk edilmesine sebep olmuş, eğitim seviyesinin yükselmesi geleneksel değerlerin aile tarafından çocuklara aktarımını zorlaştırmış ve nihayet bireyselleşme de karşılıklı ilişkileri zayıflatmıştır. Bütün bu saydığımız hususların aile üzerinde olumsuz tesirleri olması kaçınılmazdır. Biz bunlardan hiçbirisini etki açısından diğerine tercih etmiyoruz. Ancak, uygulamalı araştırmamızı incelediğimiz bölümde, eğitim seviyesinin yükselmesinin aile üzerindeki muhtemel etkilerini tartışmak istiyoruz.

Aile ile ilgili günümüzde ortaya çıkan yeni olguları, çocuk sayısında azalma, geç yaşta evlenme, partnerlik, nikâh dışı ebeveynlik, yalnız yaşama, eşcinsel evlilikler, nüfus planlaması vb. şeklinde sıralayabiliriz. Bu sonuncusunun Türkiye' de henüz gündeme gelmiş olmamasının sebebi, eşcinsellikle ilgili tartışmaların henüz son bulmamış olmasıdır. Meclis'te yeni Anayasa çalışmalarının yapıldığı şu günlerde bu konuyla bağlantılı olarak yeni Anayasa' da yer alacak cinsel özgürlüklerle ilgili çalışmalar esnasında komisyonda tartışmalar yaşandığı ana haber bültenlerine yansımıştır. Eşcinsel evlilikleri serbest bırakan Batı ülkelerinde ise, eşcinsellere evlat edinme hakkı gibi daha ileri hak arayışları gündeme gelmektedir.

Bütün bu tartışmalar aslında ailenin çocuk merkezli olmaktan uzaklaştığını göstermektedir. Son günlerde gündeme gelen kürtaj tartışmaları da aslında bu sorunun bir parçası olarak gündeme gelmiştir. Batı dünyasında da kürtaj tartışmaları zaman zaman alevlenmektedir. Youtube gibi görsel videoların yayınlandı̆̆ internet sitelerinde kürtajı kötüleyen çok sayıda görsel yayın bulunmaktadır. Bütün bu tartışmalar sonucunda nihayet Diyanet de kürtajın cinayet olduğu ve dinen caiz olmadığı şeklindeki görüşünü açıkça ilan etmiştir.

Aslında kürtaj üzerinden yürütülen tartışmalar, ebeveyn tarafından istenmeyen bir bebeğin tıbbî müdahaleyle anne karnından alınmasından çok daha öte anlamlar taşımaktadır. Tartışmanın asıl nedeni serbest cinsel yaşamın engellenmesi temeline dayanmaktadır. Eğer 
eşler arasında kazara gebe kalmaktan kaynaklanan bir sıkıntı olsaydı bu kadar şiddetli tartışmalar yaşanmazdı.

Kürtaj tartışmaları arasında gündeme getirilen bir diğer konu da cinsel eğitim tartışmalarıdır. İlk defa Batı ülkelerinde uygulanmaya başlayan, Türkiye'de de bir dönem ilköğretim öğrencilerine verilen ancak bir müddet sonra kaldırılan bu dersin nihai amacı da istenmeyen gebeliklerin önlenmesi olup bir anlamda nüfus planlaması uygulamalarının bir uzantısıdır.

Türkiye'nin son zamanlarda yürütmüş olduğu, genç ve kalabalık nüfus politikası açısından bakıldığında hükümetin kürtaj konusunda kısıtlamalara gitmek istemesi anlaşılabilir bir husustur. Avrupa'da yaşlı nüfus çoğalıp genç nüfusa ihtiyaç artınca Türkiye'dekine benzer bir kürtaj tartışmasının yeniden gündeme geleceğine hiç kuşku yoktur. Zaten şu anda bile, istenmeyen çocukların doğurularak bakıcı bir aileye verilmesini teşvik eden filmler bulunmaktadır (Juno adlı film buna örnek gösterilebilir).

Türkiye'de nüfusun azalması ile ilgili endişelerin dile getirilmesi ve hükümet tarafından en az üç çocuk sahibi olunmasının teşvik edilmesinin altında, nüfusun yaşlanma trendine girdiği ile ilgili TÜİK tarafından yayımlanan veriler yatmaktadır. TÜİK tarafından yayımlanan grafikler, Türkiye'deki nüfus artış hızının 2050 yılına kadar düzenli bir şekilde azalarak bu tarihte sıfır düzeyine geleceğini göstermektedir.

Sosyal olaylarla ilgili uzun süreli tutarlı öngörülerde bulunmak zor olduğu gibi demografi ile ilgili uzun süreli öngörülerin de problemli olabileceği söylenebilir. Örneğin Batı ülkelerinde nüfus artışının yavaşlaması ya da durması ve hatta bazı ülkelerde eksiye düşmesi göz önüne alınarak bu trendin sürekli olarak böyle devam edeceği söylenemez. Günümüz Batı dünyasının orta yaş üstü bireyleri nüfus patlaması kuşağına (baby boom) mensupturlar (Roof, 1993). İkinci dünya savaşı sonrasında yaklaşık yirmi yıllık süreçte dünyaya gelen bu insanların trend belirleyici oldukları dönemler doğum kontrolü ve az çocukluluğun teşvik edildiği dönemler olmuştur. Şu anda ise yeni trend çocuk sayısının artmasına doğru yönelmektedir. Ailelere üç çocuk önerisi Türkiye'de bizzat Başbakan tarafından sürekli olarak gündemde tutulmaktadır. Benzer bir çocuk teşviki de son zamanlarda Rusya devlet yetkilileri tarafından gündeme getirilmiştir.

Türkiye nüfusunun hiçbir zaman 100 milyonu aşamayacağı ya da nüfusun 2050 yılında durağanlaşacağı ile ilgili tahminler bugünkü veriler ışığında yapılmış olan tahminlerdir. $\mathrm{Bu}$ verilerin ortaya çıkışını hazırlayan parametrelerin değişmesi halinde bu tahminlerde sapmalar olacaktır. Gelecek yıllarda Türkiye'de çocuk sayısı ile ilgili trendin ne yönde olacağı ile ilgili bizim değerlendirmelerimiz ise uygulamalı araştırma bölümünde yer almıştır.

Türkiye' de sık sık gündeme gelen kadına şiddet, töre cinayetleri vb. tartışmalarda, bunların nedeni olarak erkek egemen toplum oluşumuzu yoğun bir şekilde gündeme 
getirmektedir. Osmanlı'nın son döneminde Ziya Gökalp ve yakın dönemlerde de Dilaver Cebeci Türk ailesini Pederî olarak nitelemişlerdir. Ailede baba egemenliği elbette toplumda da erkek egemenliği anlamına gelecektir. Ancak burada yadsınacak bir durum yoktur. İstisna olduğunu söyleyebileceğimiz kadın egemenliğinin var olduğu toplumların çoğunda da aslında çocuk üzerinde söz sahibi olan kadın değil, çocuğun anne tarafından bağlı olduğu erkek akrabalardır. Hatta bazı antropologlar dünya üzerinde erkek egemenliğinin olmadığı hiçbir toplum bulunmadığını açıkça belirtmektedirler (Haviland ve diğerleri, 2008).

Batı ailesinde ortaya çıkmış olan partnerlik, nikâh dışı ebeveynlik, yalnız yaşama, eşcinsel evlilikler gibi aile ile ilgili yeni kavram ve olguların bundan sonra Türk toplumunda daha yoğun olarak gündeme gelmesi beklenebilir. Son zamanlardaki cinsel özgürlüklerle ilgili tartışmaları buna örnek gösterebiliriz. Aileye karşı olan yaklaşımlar değiştikçe yalnız yaşama, nikâh dışı ebeveynlik ve partnerlik gibi yeni anlayışların yaygınlaşması kaçınılmazdır.

Aslında bu zikrettiğimiz hususlar Türk toplumunun fazla yabancı olmadığı şeylerdir. $\mathrm{Bu}$ yeni anlayışların Avrupa'daki şekillerine benzer olan bizdeki uygulamaları magazin programlarında sürekli olarak sergilenmektedir. Ancak, bizdeki uygulamalar Batı ailesinden kısmen farklılaşmış, bir anlamda alaturkalaşmıştır.

Örneğin, 2003 yılında Avrupa Birliği içerisinde yer alan EU-25 ülkelerinde doğan her yüz çocuktan 30,2'si evlilik dişı doğmuştur (Daly, 2006). Bu rakam Türkiye için oldukça yüksek bir rakamdır. Türkiye' de de evlilik dışı doğan çocuklar elbette vardır ve bunların durumu Medeni Kanunun 292, 295 ve 301. Maddeleri ile 5490 sayılı Nüfus Hizmetleri Kanununda düzenlenmiştir. Bu konu ile ilgili olarak Türkiye'ye özgü durum ise dini nikâh ile evlenenlerin durumudur. Medeni Kanuna göre, resmi nikâh yaptırmayıp sadece dini nikâh yaptıranların çocukları evlilik dışı çocuk kapsamına girmektedir. 1988 yılı verilerini gösteren Türk Aile Yapısı Araştırması dini nikâhın toplumda genel bir kabul gördüğünü ortaya koymuştur. Dinî nikâhın en az görüldüğü Batı Anadolu bölgesinde bile dini nikâh oranı \% 84,80 olarak gerçekleşmiştir. Bu oran Güney Anadolu, İç Anadolu, Karadeniz, Doğu ve Güneydoğu Anadolu bölgelerinin tamamında ise \% 90'ların üzerindedir (TAYA, 1993). 2007 yılında ise İstanbul evreninde bu oran \%78,8 olarak ölçülmüştür (Yılmaz, 2008).

Dini nikâhın toplumda bu ölçüde kabul görmesi, evli olanların ikinci bir eş ile evlenmelerinin kanunen mümkün olmaması nedeniyle bu yola başvurmalarına neden olduğu gibi, boşanırken de mahkeme huzuruna çıkmak ya da boşanan kadına kanunun verdiği hakları vermek gibi yükümlülüklerden kaçınmak amacıyla da bu yola başvurulabilmektedir. Bütün bunların yanında Batı'daki partnerlik anlayışına benzer şekilde, evliliğin maliyetinden kaçınmak, ayrılırken sorun yaşamamak ve kısa süreli beraberlik düşünceleri de genellikle dini nikâha başvurulmasına neden olmaktadır. Bu şekilde toplum baskısı ortadan kalktığı gibi eşler de günaha girme psikolojisinden kurtulmaktadır. 
Aile ile ilgili ortaya çıkan yeni bulgulardan bir tanesi de boşanmaların artmasıdır. Boşanmaların artması yalnız yaşama tercihlerinin artığının habercisidir. Bu da aile ile ilgili yeni bir durumdur. TÜİK verileri incelendiğinde boşanma oranlarının son 30 yılda neredeyse 5 kat arttığı görülmektedir. 1980 yılında evlenen sayısı 366403, boşanan sayısı ise 15901 olup E/B oranı \%4,34 olarak gerçekleşmiştir. 2010 yılında ise evlenen sayısı 582715 kişi olurken boşanan kişi sayısı 118568 olarak gerçekleşmiş ve E/B oranı \%20,34’e yükselmiştir. Boşanma oranlarında özellikle son on yılda müthiş bir artış gözlemlenmiştir.

Aile ile ilgili ortaya çıkan bu yeni olgular acaba Türk ailesini ve Türk toplumunu nasıl etkileyecektir? Gelecekte Türk ailesini nasıl bir değişim beklemektedir? Bu makalenin uygulamalı araştırma bölümü, aile ile ilgili değişimlerin, Avrupa'daki örneklerinde olduğu gibi (Daly, 2006), genç yaştaki arkadaşlık grupları ve üst sosyal sınıflar tarafından tetiklendiği gerçeğinden yola çıkarak, üniversite öğrencilerinin evlilik ve aileye bakışları ile ilgili bazı empirik veriler ışı̆̆ında bu sorulara cevap aramaktadır.

\section{Araştırmanın Konusu, Amacı ve Yöntemi}

$\mathrm{Bu}$ araştırma genel olarak aile ile ilgili yaklaşımlarda meydana gelen değişimleri, özelde ise eğitim seviyesinin yükselmesinin aile ile ilgili anlayışlarda ne gibi değişikliklere yol açtığını konu edinmektedir.

Araştırmanın amacı, eğitim seviyesi gelişmiş ülkelerin oldukça altında olan, ancak genç nesilde yüzde yüze yakın bir okuryazarlık seviyesi yakalayan, zorunlu eğitimi 12 yıla çıkaran ve her ilde üniversite projesiyle yükseköğrenim düzeyini artırmaya devam eden Türkiye' de eğitim seviyesinin yükselmesine paralel olarak toplumun aile anlayışında ne gibi değişiklikler olabileceğini tespit etmeye çalışmaktır. Araştırma, bu yönüyle aile politikalarına da ilham verebilecektir.

Araştırmada TÜİK verileri taranmış, konu ile ilgili daha önce yapılmış benzer çalışmalar incelenmiş ve anket tekniği kullanılarak üniversite öğrencilerinin evlilik ve aile ile ilgili düşünceleri hakkında veriler toplanmıştır.

\section{Evren ve Örneklem Seçimi}

Araştırma evrenini, Karabük Üniversitesinde okuyan öğrenciler oluşturmaktadır. Örneklem seçimi ise Karabük Üniversitesi öğrencilerinin \%2'sine karşılık gelecek şekilde rastgele yapılmış, ancak anketi dolduran kız ve erkek öğrencilerin birbirine yakın sayıda olmalarına dikkat edilmiştir. Örneklem seçimi yapılırken belirli fakülte ya da bölümlere öncelik verilmemiş, ancak bazı bölümlerde üst sınıflarda öğrenci bulunmaması nedeniyle bu bölümlere daha az sayıda anket formu dağıtılabilmiştir. 
Anket formları fotokopi yoluyla 350 adet basılarak öğrencilere ulaştırılmıştır. Dağıtılan anket formlarından 339 tanesi geri gelmiş ve tamamı değerlendirmeye alınmıştır. Anket verileri SPSS programıyla analiz edilmiş ve frekans tabloları makale içerisinde uygun yerlere yerleştirilmiştir. Merkezi dağılım ölçülerinden Standart sapma ve aritmetik ortalamalar (Mean) incelenerek önemli bulunan sonuçlara yine metin içerisinde yer verilmiştir. Araştırma değişkenlerinin bağımsız değişkenlerle olan çapraz ilişkilerine de bakılmış olup, anlamlı ilişki bulunan tabloların verilerine bakılarak metin içerisinde yorumlar yapılmıştır. Ancak makalenin boyutunun artmaması için bu tablolarla ilgili tüm verilere yer verilememiştir.

\section{Sayıltı ve Varsayımlar}

Araştırmanın temel sayıltısı, "cinsiyetler arası farklılıklar, bölgesel farklılıklar ve sosyo-ekonomik farklılıklar evlilik ve aile ile ilgili duygu ve düşüncelere etki etmektedir." şeklinde ifade edilebilir.

Araştırmanın varsayımlarını ise aşağıdaki şekilde sıralayabiliriz:

- Türkiye'de eğitim seviyesinin yükselmesi geleneksel aile modellerinden uzaklaşmaya neden olacaktır.

- Yükseköğrenim görenler, farklı sosyo-ekonomik düzey ve farklı sosyo-kültürel ortamlardan gelmiş olsalar bile, evlilik ve aile konusunda benzer düşüncelere sahiptir.

\section{Araştırma Bulguları}

\section{Araştırma Grubunun Cinsiyet, Yaş, Sosyo-Ekonomik ve Sosyo-Kültürel Düzeyleri ile İlgili Bulgular}

Araştırmanın evlilik ve aile konusuna odaklanmış olması nedeniyle araştırmanın temel bağımsız değişkeni elbette cinsiyet değişkeni olmuştur. Buna ek olarak evlilik ve aile ile ilgili duygu, düşünce ve yaklaşımlar üzerinde etkili olduğunu düşündüğümüz sosyo-ekonomik farklılık, sosyo-kültürel farklılık ve yaş farkı gibi değişkenler anket soruları arasına dâhil edilmiştir.

Araştırma evrenini sadece öğrencilerin oluşturduğu bir araştırmada yaş değiş̧keninin dikkate alınması ilk bakışta anlamsız gibi gözükebilir. Ancak, üniversite öğrencileri arasında doğrudan yaşı belirlemeye yönelik değil de sınıf düzeyini belirlemeye yönelik bir soru oldukça anlamlı olacaktır. Çünkü üniversiteye yeni gelen öğrenciler henüz ailelerinin etkisi 
altında olabilecekleri halde, sınıf atladıkça ve eğitim düzeyleri yükseldikçe ailelerinin kendilerine bakış açısı değişeceği gibi, çevrelerinin artık kendilerine saygı duymaya, bilgi ve tecrübesine güvenmeye başladığını gören öğrencilerin de görüş ve düşüncelerinde farklılıklar olacaktır. İşte bu noktadan hareketle öğrencilere doğrudan yaşları sorulmamış, ancak dolaylı olarak bu değişkenle ilintili olan kaçıncı sınıfta okudukları sorusu kendilerine yöneltilmiştir. Araştırma bulgularına göre ankete katılan hazırlık ya da 1. Sınıf öğrencilerinin oranı \%57,2, 2 . ve 3. Sınıf öğrencilerinin oranı \%12,7 ve son sınıf öğrencilerinin oranı da \%30,1 düzeyindedir. Hazırlık ve 1. Sınıf öğrencileri ile son sınıf öğrencilerinin oranlarının yüksek olmasının nedeni, yukarıda da ifade ettiğimiz gibi yaş farkından ya da diğer bir ifadeyle eğitim düzeyinin yükselmesinden kaynaklanan farklılıkların ölçülmek istenmesidir.

Araştırma evreninin öğrencilerden oluşması nedeniyle sosyo-ekonomik farklılıkları ölçmek için kendilerine ailelerinin gelir düzeyleri sorulmuştur. Araştırmacı tarafından Türkiye' nin mevcut ekonomik durumu göz önüne alınarak aylık geliri 1500 TL'ye kadar olan aileler alt gelir grubu, 1501-3000 TL arası geliri olan aileler orta gelir grubu ve 3000 TL'den fazla geliri olan aileler de üst gelir grubu olarak kategorize edilmiştir. Araştırma bulgularına göre öğrencilerin \%60,9'u alt sosyo-ekonomik sınıfa mensuptur. Geriye kalanların \%32,8'i orta sosyo-ekonomik sınıfa ve \%6,3'ü de üst ekonomik sınıfa mensup ailelerin çocuklarıdır. Genel ortalama dikkate alındığında öğrencilerin alt sosyo-ekonomik grup ile orta sosyoekonomik grup arasında kaldığı anlaşılmaktadır.

Araştırmanın son bağımsız değişkeni öğrencilerin gelmiş oldukları sosyo-kültürel ortam ile ilgilidir. Aile ile ilgili yapılmış olan pek çok araştırma, kültürel farklılıkların aile ile ilgili düşünce ve yaklaşımlar üzerinde etkili olduğunu ortaya koymuştur. Kültürel ortamların belirlenmesi elbette zordur. Ancak coğrafya faktörünün sosyolojide oldukça önemsenmesi hatta bazı kuramcıların görüşlerinin bu başlık altında toplanmasından hareketle öğrencilerin ikamet yerleri olan illerin yer aldı̆̆ı bölgeler dikkate alınarak kültürel farklılıklar incelenmeye çalışılmıştır. Doğu ve G. Doğu Anadolu'nun, diğer bölgelere oranla birbirlerine daha fazla benzeşeceği kabul edilerek bu iki bölge birleştirilerek tek bir başlık altında toplanmıştır. Araştırma bulgularına göre Öğrencilerimizin büyük çoğunluğunu Marmara bölgesinden gelen öğrenciler oluşturmakta $(\% 39,9)$, bunu da Karadeniz bölgesi takip etmektedir $(\% 24,0)$. Diğer bölgelerden gelen öğrencilerin oranları ise bu iki bölgeyle mukayese edildiğinde görece olarak düşük kalmıştır [İç Anadolu $(\% 13,6)$, Akdeniz $(\% 8,6)$, Doğu ve G. Doğu Anadolu $(\% 8,6)$, Ege $(\% 5,3)]$. Yukarıdaki verilerin incelenmesinden de anlaşılabileceği gibi, araştırma değişkenlerinin standart sapmaları incelendiğinde, en yüksek standart sapmaya sahip olan değişkenin bölgesel farklılıklarla ilgili değişkenimiz olduğu görülmüştür $(1,792)$. Araştırma evrenimizden kaynaklanan bu problem nedeniyle çapraz ilişki tablolarında bölge farklılığına dayalı olarak derinlemesine analiz yapılmasından kaçınılacaktır. 


\section{Araştırma Grubunun Evlilik Kararlarını Nasıl Vereceklerine Yönelik Bulgular}

Modern toplumlar, diğer pek çok konuda olduğu gibi, evliliğe karar verme konusunda da modern öncesi toplumlardan farklılaşmaktadır. Modern çağın gerekleri geçmişteki uygulamaları ya tamamen değiştirmekte ya da geçmiş uygulamaların form değiştirerek yaşamalarına izin vermektedir. Mesela, evliliklerde görücü usulü Osmanlı Devletinin son zamanlarından günümüze kadar tartışılagelen bir husustur (Duben-Behar, 1996). Ancak günümüzdeki görücü usulü kavramı biraz farklılaşmış ve gelin ile damadın ancak düğün gecesi birbirini görebildiği evlilik modeli ortadan kalkmıştır. Görücü usulü ile artık erkek tarafının önce kız ailesini ziyaret ederek kızı ve ailesini beğendikten sonra oğullarına haber vermeleri ve daha sonra kız ile erkeğin tanıştırılması şeklindeki bir model anlaşılmaktadır (Y1lmaz, 2005).

Teknolojinin gelişmesi de evliliğe karar verme konusunda farklı modellerin gelişmesine imkân vermiştir. İnternetin yaygınlaşmaya başladığı ilk yıllarda birbirini hiç görmeden chat/sohbet yaparak birbirine âşık olanlar ve evlenenler sanki modern zamanların görücü usulü ile evlenenleri gibidir. Ancak teknolojideki hızlı değişmeler bu örnekleri çabucak yok etmiştir. Tüm dünyada olduğu gibi Türkiye'de de yaygın olarak kullanılan Msn ve Skype gibi görüntülü konuşmaya imkân veren programlar ile $3 \mathrm{G}$ telefonlar karşı cinslerin birbirleriyle özgürce görüşmelerine imkân sağlarken, Facebook gibi programlar da arkadaş arama, bulma, tanıma gibi amaçlarla kullanılmaktadır.

Yukarıda belirttiğimiz bu yeni modeller, evliliğe karar verirken genellikle ailenin devre dışı kaldığı modellerdir. Evlilik kararında geleneksel anlayışlardaki değişmeleri belirlemek üzere araştırma grubuna bazı sorular yöneltilmiş ve sonuçlar aşağıda Tablo 1 'de gösterilmiştir.

Tablo 1: Evlilik Kararma Ailenin Etkisi İle İlgili Bulgular

\begin{tabular}{|l|c|c|c|}
\hline & F & Yüzde \% & Geçerli \% \\
\hline Ailem bana karışmaz. Kararı kendim veririm. & 44 & 13,0 & 13,0 \\
\hline Kararı ben veririm. Ancak aileme de danışırım. & 195 & 57,5 & 57,5 \\
\hline $\begin{array}{l}\text { Ailemin karışmasını istemesem de onlar karışırlar. Bu } \\
\text { konuda onlarla mücadele ederim. }\end{array}$ & 11 & 3,2 & 3,2 \\
\hline $\begin{array}{l}\text { Ailemle birlikte karar alırız. Karşı1ıklı olarak } \\
\text { birbirimizi ikna ederiz. }\end{array}$ & 74 & 21,8 & 21,8 \\
\hline $\begin{array}{l}\text { Ailemin görüşü ağır basar. Ben de onların görüşü } \\
\text { doğrultusunda hareket ederim. }\end{array}$ & 10 & 2,9 & 2,9 \\
\hline Ailem ne derse o olur. Benim bir söz hakkım olmaz. & 5 & 1,5 & 1,5 \\
\hline Toplam & 339 & 100,0 & 100,0 \\
\hline
\end{tabular}


Araştırma grubunun \%13'ü evlilik kararı verirken ailesinin kendisine karışmayacağını belirtmiştir. \%57,5'i ise kararı kendisinin vereceğini ancak ailesine de danışacağını söylemiştir. $\mathrm{Bu}$ oranlara bakarak Türkiye'de ilerleyen zamanlarda eğitim seviyesinin yükselmesine paralel olarak evlilik kararlarında ailenin daha fazla devre dışı bırakılacağı ve bireysel tercihlerin artacağı söylenebilir.

Yapmış olduğumuz ki-kare analizi sonucunda, evlilik kararına ailenin etkisi ile cinsiyet değişkeni arasında oldukça anlamlı bir ilişki görülmüştür ( $\mathrm{P}=0,000)$. Türkiye'nin toplum yapısını bilen herkesin rahatlıkla söyleyebileceği gibi, bu farklılık kız çocuklarına ailelerin daha fazla müdahale etmek istemesinden kaynaklanmaktadır. Öğrencilerin farklı bölgelerde ikamet etmeleri de evlilik kararları üzerinde anlamlı bir farklılığa yol açmıştır $(\mathrm{P}=0,007)$. Öğrencilerin farklı sınıfta olmaları da aynı şekilde evlilik kararlarına anlamlı şekilde etki etmiştir ( $\mathrm{P}=0,004)$.

Türkiye'nin farklı bölgeleri, eğitim seviyesi, sosyo-ekonomik ve sosyo-kültürel gelişmişlik açısından farklı özellikler göstermektedir. Dolayısıyla öğrencilerin farklı bölgelerden gelmeleri, bazen kendi tercihleri olmasa bile, onları ailelerinin isteklerini yerine getirmeye ve âdetlere uymaya zorlayabilir. Bununla birlikte örneklemimizin \%70'ten daha fazla bir bölümü evlilik kararlarını kendilerinin vereceğini belirtmiştir.

2006 aile yapısı araştırmasında da evlilik kararlarında kız çocukları için ailenin karar verme oranlarının daha yüksek bulunduğu görülmektedir. Ailesinin bilgisi dışında veya ailesinin karşı çıkmasına rağmen evlenenlerin oranı yaklaşık \% 8'ler düzeyindedir. Bizim elde etmiş olduğumuz bulgular ise eğitim seviyesinin yükselmesinin evlilik kararlarında ailenin etkisinin bir miktar azalmasına neden olacağını göstermektedir.

Evlilik kararlarında bireysel tercihlerin artması ve ailenin devre dışı kalması kurulan ailelerde ilerleyen dönemde çözülmelere yol açabilir. Aile sadece iki kişiyi değil aynı zamanda onların ailelerini de ilgilendiren bir kurumdur. İki kişi birbirini sevse bile aile ve çevrelerinden gördükleri baskılar aile içi ilişkileri yıpratabilir. Bu durum ileride boşanma oranlarının artmasına kısmî bir katkı yapabilir. Bu sözlerimiz, modern öncesi dönemlerde olduğu gibi çocukların evlenmeleri üzerinde sadece ebeveynlerin söz sahibi olduğu bir modeli yücelttiğimiz anlamına gelmemektedir. Eğer zamanın bir ruhu varsa, o dönemin insanları kendi zamanlarının ruhuna uymuşlardır. 15, 16, 17 gibi yaşlardaki çocukların evlenmelerinin yaygın olduğu ve genel bir kabul gördüğü dönemde "Büyükler bu işe karışmasın. Çocuklar kendileri karar versinler" gibi bir söz söylemek herhalde doğru olmazdı. Günümüzde ise ortalama evlenme yaşı Erkeklerde 26,6 kadınlarda ise 23,3'e ulaşmıştır. Buna ek olarak yeni jenerasyonun eğitim seviyesi de kendinden önceki jenerasyonlara oranla oldukça yükselmiştir. Evlenmek için eğitimini tamamlamayı bekleyen ve iyi gelirli bir iş bulana kadar bekleyen gençler ekonomik olarak da ailelerinden bağımsızlaşmaktadır. Bu durumda aileler 
de çocuklarına karışmayı uygun görmemekte, onların kararlarını onaylamayı tercih etmektedir.

Araştırma grubunun tercih ettiği evlenme yöntemi ile ilgili bulgular Tablo 2'de gösterilmiştir. Evlilik kararlarında bireysel tercihlerin artması, erkek çocuğu olan annelerin, çocukları için kız baktığı geleneksel modelden uzaklaşılmasına sebep olmuştur. Aile ortamında tanışarak evlenmek isteyen gençlerin oranı görece olarak düşük kalmıştır $(\% 10,4)$.

Tercih edilen evlenme yöntemi cinsiyete göre anlamlı bir farklılık göstermektedir $(\mathrm{P}=0,008)$. Duygusal bir arkadaşlıktan sonra evlenmeyi isteyenlerin oranı kızlarda daha yüksek çıkmıştır ( $\mathrm{E}=\% 26,3 ; \mathrm{K}=\% 34)$. Aile ortamında tanışarak evlenmeyi benimseme oranı ise erkeklerde daha yüksektir $(\mathrm{E}=\% 7,5 ; \mathrm{K}=\% 3)$. Bu sonuçlar, eğitim seviyesi yükselen kızların, evlerinde oturarak kendilerine görücü gelmesini fazla tasvip etmediklerini göstermektedir.

Tercih edilen evlenme yöntemi ile ilgili olarak bölgesel bir farklılığa ise rastlanmamıştır. Bu sonuca dayanarak eğitim seviyesi yükseldikçe bölgesel fark ve çeşitliliklerin azaldığı söylenebilir.

Tablo 2: Tercih Edilen Evlenme Yöntemi ile İlgili Bulgular

\begin{tabular}{|l|c|c|c|}
\hline & F & Yüzde \% & Geçerli \% \\
\hline $\begin{array}{l}\text { Bir süre duygusal arkadaşlık yaptığınız kişiyi ailenizle } \\
\text { tanıştırdıktan sonra evlenmek }\end{array}$ & 202 & 59,6 & 60,3 \\
\hline $\begin{array}{l}\text { Aile ortamında tanışı̆̆ınız bir kişiyle görüşüp } \\
\text { anlaşarak evlenmek }\end{array}$ & 35 & 10,3 & 10,4 \\
\hline $\begin{array}{l}\text { Evlenme amacıyla tanıştığınız birisini daha sonra } \\
\text { ailenize tanıtmak ve sonra evlenmek. }\end{array}$ & 98 & 28,9 & 29,3 \\
\hline Cevapsız & 4 & 1,2 & \\
\hline Toplam & 339 & 100,0 & \\
\hline
\end{tabular}

\section{Evlilik ve Aile Kurma ile İlgili Düşünceler}

Günümüz ailesini geçmişten farklı kılan en önemli özelliklerden birisi de evliliklerin geciktirilmesidir. Avrupa'da olduğu gibi Türkiye' de de evlilik yaşı son birkaç on yılda önemli oranda yükselmiştir (Tezcan\&Coşkun; 2004). Evlenme yaşının yükselmesinin doğal sonucu olarak da kadınlarda doğurganlık oranları düşmekte ve ailelerdeki çocuk sayısı azalmaktadır. TÜİK verilerine göre 1985 yılında ortalama ilk evlenme yaşı erkeklerde 25,5 ve kadınlarda ise 21,8 iken bu rakamlar düzenli olarak yükselerek 2005 yllında erkeklerde 27,5 ve kadınlarda 23,6' ya yükselmiştir. 
Evlenme ve boşanma istatistikleri 2002 yılına kadar Türkiye İstatistik Kurumu (TÜİK) tarafından belediyeler, nüfus müdürlükleri ve muhtarlıklar aracılığı ile derlenirken, 2003 yılından itibaren Merkezi Nüfus İdaresi Sistemi'nden (MERNIS) elde edilmeye başlanmıştır (TÜİK, 2008). Bunun sonucu olarak 2006 yllından itibaren TÜİK verilerinde farklılıklar oluşmuş ve ortalama ilk evlenme yaşı rakamlarında küçük düşüşler görülmüştür. 2011 yılı verilerine göre ortalama ilk evlenme yaşı erkeklerde 26,6 iken bu rakam kadınlarda 23,3 olarak gerçekleşmiştir (TÜIK, 2012b).

Evlenme ve boşanma istatistiklerinin sadece MERNiS aracılığı ile derlenmesi, evlenirken dini ve resmi nikâhı bir arada yaptıranların dışında kalan ve sadece dini nikâh kıydıran kişilere ait rakamların göz ardı edilmesine neden olabilir. Türkiye'de dini nikâh kıydırma olgusu sadece evlenirken gündeme gelen bir olgu değildir. Devletin yapmış olduğu para yardımlarından yararlanabilmek için resmi olarak boşandığı halde birlikte yaşamaya devam eden eşlerin sayısı da azımsanamayacak derecededir.

Aşağıda yer alan Tablo 3'te araştırma grubunun dini nikâh yaptırmanın gerekliliği ile ilgili düşüncelerine yer verilmiştir. Dini nikâh yaptırmayı hiç gerekli görmeyenlerin oranı görece olarak oldukça düşüktür (\%8). Dini nikâh yaptırmanın fazla ya da çok fazla gerekli olduğunu düşünenlerin oranı ise toplam \%78,4 oranında olup bu konuda yapılmış daha önceki araştırmaların sonucuna oldukça yaklaşmıştır.

2007 yılında yapmış olduğumuz bir diğer araştırmada da dini nikâh olgusunun, eğitim düzeyi, gelir düzeyi ve kentlileşme düzeyi gibi hiçbir bağımsız değişkene bağlı olarak farklılaşmadığı tespit edilmiştir (Yılmaz, 2008). Buradaki rakamların da bir kez daha teyit ettiği gibi dini nikâh olgusu toplumun hemen her kesimi tarafından yaygın bir şekilde kabul gören bir olgudur. Buradan yola çıkarak, Batı'da gittikçe yaygınlaşmaya başlayan partnerlik ya da evlilik dışı beraberliklerin Türkiye'de daha çok dini nikâh şemsiyesi altında devam edeceği söylenebilir.

\begin{tabular}{|l|c|c|c|}
\hline \multicolumn{4}{|c|}{ Tablo 3: Dini Nikâh Yaptırmanın Gerekliliği İle İlgili } \\
& F & Yüzünde $\%$ & Geçerli \% \\
\hline & 27 & 8,0 & 8,0 \\
\hline Hiç & 21 & 6,2 & 6,2 \\
\hline Çok az & 25 & 7,4 & 7,4 \\
\hline Biraz & 45 & 13,3 & 13,3 \\
\hline Fazla & 220 & 64,9 & 65,1 \\
\hline Çok fazla & 1 &, 3 & \\
\hline Cevapsız & 339 & 100,0 & \\
\hline Toplam & & & \\
\hline
\end{tabular}

Dini nikâh, her ne kadar toplumda genel bir kabul görüyor olsa da devlet ya da yasalar nezdinde geçerli bir uygulama değildir. Dolayısıyla dini nikâh yaptıranların, mağdur olmaları 
durumunda başvurabilecekleri kanuni yollar kapalıdır. Bu durum, resmi nikâh yaptırmadan sadece dini nikâh yaptırmanın bazı sakıncaları olabileceğini göstermektedir. Bütün bunlara ilaveten günümüzde dini nikâh, şer’i hukukun geçerli olduğu dönemde yerine getirdiği işlevlerin hiçbirini yerine getirememektedir. Örneğin, günümüzde dini nikâh yaptıran kadınların mehir hakları kocalarının insafına kalmıştır. Çocuğun nesebinin tescil edilmesi ve çocuğun babasının mirasından pay alabilmesi kavga ve gürültüsü eksik olmayan uzun davalara neden olmaktadır. Boşanan kadının nafaka hakkı ve sükna hakkı gibi hakları gündeme bile gelmemektedir (Karaman, 1996).

Dini nikâhın bu tür sakıncaları ile ilgili araştırma grubumuzun ne tür düşüncelere sahip olduğuna yönelik veriler aşağıda Tablo 4'te gösterilmiştir. Dini nikâh yaptırmakta hiçbir sakınca olmadığını söyleyenlerin oranı $(\% 8,9)$ ile dini nikâh yaptırmanın fazla ya da çok fazla gerekli olduğunu düşünenlerin toplam oranı $(\% 78,4)$ karşılaştırıldığında ortaya oldukça anlamlı bir durum çıkmaktadır. Buradan anlaşıldığına göre, araştırma grubumuz dini inançları sebebiyle dini nikâh yaptırmayı büyük oranda gerekli ve makul görmekte, ancak resmi nikâh yaptırmadan sadece dini nikâh yaptırmanın sakıncalarının da bilincinde olduğunu göstermektedir.

\begin{tabular}{|l|c|c|c|}
\hline \multicolumn{4}{|c|}{ Tablo 4: Sadece Dini Nikâh Yaptırmanın Sakıncaları Íle İlgili } \\
& F & Yüzde \% & Geçerli \% \\
\hline Hiç & 30 & 8,8 & 8,9 \\
\hline Çok az & 24 & 7,1 & 7,1 \\
\hline Biraz & 42 & 12,4 & 12,4 \\
\hline Fazla & 50 & 14,7 & 14,8 \\
\hline Çok fazla & 192 & 56,6 & 56,8 \\
\hline Cevapsız & 1 &, 3 & \\
\hline Toplam & 339 & 100,0 & \\
\hline
\end{tabular}

Resmi nikâh yaptırmayıp sadece dini nikâh yaptırarak birlikte yaşayanları hariç tutacak olursak, TÜİK verilerine göre Türkiye'de nikâhsız birlikte yaşayanların oranının oldukça düşük olduğunu söyleyebiliriz $(\% 0,6)$. Yalnız dini nikâh yaptıranların oranı \%3,7 iken, resmi ve dini nikâhı bir arada yaptıranların oranı ise \%85,9 düzeyindedir (TÜİK, 2006).

Araştırma grubumuzda nikâhsız birlikte yaşamayı onaylama oranları aşağıda Tablo 5'te gösterilmiştir. Nikâhsız birlikte yaşamayı hiç onaylamayanların oranı \%77 olarak ölçülmüştür. Bunun dışında kalan \%23'lük bir orana sahip kesimin ise az ya da çok nikâhsız birlikte yaşamayı onayladıkları anlaşılmaktadır. Ancak, örneklem grubumuzun bekâr ve çok genç olmaları dikkate alındığında ilerleyen yıllarda bu anlamda biraz daha muhafazakârlaşmaları beklenebilir. Bununla birlikte, Türkiye'de eğitim seviyesinin yükselmesine paralel olarak nikâhsız birlikte yaşama oranlarında da yükselmeler olması kaçınılmazdır. 


\begin{tabular}{|l|c|c|c|}
\hline \multicolumn{3}{|c|}{ Tablo 5: Nikâhsız B irlikte Yaşamayı Onaylama Oranları } \\
\hline & F & Yüzde $\%$ & Geçerli \% \\
\hline Hiç & 261 & 77,0 & 77,0 \\
\hline Çok az & 28 & 8,3 & 8,3 \\
\hline Biraz & 33 & 9,7 & 9,7 \\
\hline Fazla & 9 & 2,7 & 2,7 \\
\hline Çok fazla & 8 & 2,4 & 2,4 \\
\hline Toplam & 339 & 100,0 & 100,0 \\
\hline
\end{tabular}

TÜíK verilerine göre Türkiye genelinde 18 ve üzeri yaşta evli bireyler içinde akraba evliliği yapanların oranı \%20,9'dur. Akraba evliliği yapma oranları Türkiye'nin farklı bölgelerine göre değişiklik arz etmektedir. Akraba evliliğinin en yüksek olduğu bölge \%40,4 ile Güneydoğu Anadolu bölgesi olmuştur.

Eğitim seviyesinin yükselmesine bağlı olarak Türkiye' de akraba evliliklerinde azalma olup olmayacağını belirlemek üzere araştırma grubuna akraba evliliklerini onaylama dereceleri sorulmuş ve sonuçlar Tablo 6'da gösterilmiştir. Akraba evliliğini hiç onaylamayanların oranı \%63,7 düzeyindedir. Akraba evliliğini fazla ya da çok fazla onaylayanların toplam oranı ise \%6,4 düzeyindedir. Bu grubun, akraba evliliği yapma potansiyeline sahip olanları temsil ettiği düşünülebilir. Geriye kalan $\% 18$ oranındaki grubun ise, kendisi akraba evliliği yapmayı düşünmediği halde bu tür evliliklere karşı olmayanları temsil ettiğini söyleyebiliriz.

\begin{tabular}{|l|c|c|c|}
\hline \multicolumn{4}{|c|}{ Tablo 6: Akraba Evliliğini Onaylama Oranları } \\
\hline & F & Yüzde \% & Geçerli \% \\
\hline Hiç & 216 & 63,7 & 63,7 \\
\hline Çok az & 50 & 14,7 & 14,7 \\
\hline Biraz & 51 & 15,0 & 15,0 \\
\hline Fazla & 10 & 2,9 & 2,9 \\
\hline Çok fazla & 12 & 3,5 & 3,5 \\
\hline Toplam & 339 & 100,0 & 100,0 \\
\hline
\end{tabular}

Türkiye' nin Avrupa Birliği ile müzakere sürecinde olması ve bazı birlik ülkelerinde eşcinsel evliliklerin serbest olması nedeniyle, eşcinsellik konusu Türkiye'de zaman zaman gündeme gelmektedir. Hassas ve tepki gösterilebilecek bir konu olması nedeniyle daha önceki araştırmalarda kendisine yer bulamayan bu konunun, cinsel özgürlüklerin tartışıldığı şu günlerde araştırma konusu edilmesi anlamlı olacaktır. 
Araştırma grubunun eşcinsel evlilikten rahatsız olma oranları aşağıda gösterilmiştir (Tablo 7). Araştırma grubunun \%20,9'u, eşcinsel evliliklerin kendisini hiç rahatsız etmeyeceğini belirtmiştir. Eşcinsel evliliklerin, kendisini fazla ya da çok fazla rahatsız edeceğini belirtenlerin toplam oranı ise \%65,5 düzeyindedir. Geriye kalan grup ise, eşcinsel evliliklerden kısmî rahatsızlık duyanları temsil etmektedir.

Ki-kare analizi sonucunda, eşcinsel evlilikten rahatsız olma ile cinsiyet arasında anlamlı bir ilişki olduğu görülmüştür $(\mathrm{P}=0,025)$. Çapraz ilişki tabloları incelendiğinde eşcinsel evliliklere bayanların daha olumsuz baktıkları görülmüştür. Diğer bağımsız değişkenler ise anlamlı bir farklılığa neden olmamıştır.

\begin{tabular}{|l|c|c|c|}
\hline \multicolumn{4}{|c|}{ Tablo 7: Eşcinsel Evilikten Rahatsız Olma Oranları } \\
\hline & F & Yüzde \% & Geçerli \% \\
\hline Hiç & 71 & 20,9 & 20,9 \\
\hline Çok az & 26 & 7,7 & 7,7 \\
\hline Biraz & 20 & 5,9 & 5,9 \\
\hline Fazla & 29 & 8,6 & 8,6 \\
\hline Çok fazla & 193 & 56,9 & 56,9 \\
\hline Toplam & 339 & 100,0 & 100,0 \\
\hline
\end{tabular}

\section{Tercih Edilen Çocuk Sayısı ve Evlenme Yaşı İle İlgili Bulgular}

İstatistik veriler 1şı̆̆ında yapılan nüfus projeksiyonları, Türkiye' de nüfus artış hızının 2050 yılında duracağını ve bu tarihte nüfusun 100 milyona ulaşarak sabitleneceğini belirtmektedir. Bize göre ise nüfusun 100 milyona ulaşması 2040'l1 yılların hemen başında gerçekleşecek ve nüfus artış hızı oldukça düşmüş olmakla birlikte sıfır düzeyine gerilemeyecektir.

İstatistik verilerin de gösterdiği gibi Türkiye'de şu anda nüfus artış hızında bir gerilemenin olduğu açıktır. Ancak nüfus artış hızındaki bu gerilemenin altında Türkiye'ye özgü bazı durumlar bulunmaktadır. Mesela, Türkiye'de nüfus artış hızını yavaşlatan en önemli etkenlerden birisi kentleşmedir. Fakat Türkiye'de 1950'lerden sonra şehirlere olan hızlı göç dalgası artık durma noktasına gelmiştir. Cumhuriyet'in ilk kurulduğu dönemlerde nüfusun sadece dörtte biri şehirlerde yaşarken, bu oran günümüzde \%76,8 düzeyine ulaşmıştır (TÜİK, 2012c). Nüfus artış hızını etkileyen en önemli etkenlerden birisi de eğitim seviyesinin yükselmesidir. Türkiye'de 8 yıllık zorunlu eğitimin 12 yıla çıkarılması sonrasında bu öğrencilerin pek çoğunun üniversiteye devam etmek isteyeceklerini de göz önüne alırsak evlilik için gerekli ekonomik bağımsızlı̆ı kazanmak için gençlerin daha fazla zamana ihtiyaçları olacaktır. Türkiye'de son yıllarda her ile üniversite kurulması da kontenjan problemini kısa bir süre sonra ortadan kaldıracağı için üniversiteye gitme oranları da oldukça 
yükselecektir. Eğitim sürecinin uzamasına bağlı olarak evlenme yaşları da yükselecek ve buna bağlı olarak da çocuk sayısı azalacaktır.

Eğitim seviyesinin yükselmesi ve kentleşme oranının yüksek olması her ne kadar nüfus artış hızını olumsuz etkilese de tamamen sıfırlanmasına neden olacağını söyleyebilmek mümkün değildir. Eğitim seviyesi ve kentleşme oranı açısından birbirine benzer verilere sahip olan Batı ülkelerinde farklı nüfus artış hızları görülebilmektedir. Mesela tüm Avrupa genelinde yıllık nüfus artış hızı \%0,1 düzeyindedir. EU-27 ülkelerinde bu oran \%0,3'e yükselmektedir. ABD'nin yıllık nüfus artış hızı ise \%1,0'dır (EUROSTAT, 2012a). O halde nüfus artış hızının kültürel değerlerle de ilişkisi olduğu düşünülmelidir.

Bütün bunlara ilaveten Türkiye'de nüfus artış hızının sıfırlanmayacağına yönelik en önemli verilerden birisi kadınların işgücüne katılım oranlarıdır. EU-27 ülkelerinde kadınların işgücüne katılım oranı \%62,3 düzeyindedir (EUROSTAT, 2012b). Türkiye'de ise bu oran \%28,5 düzeyindedir. Ancak yükseköğretim mezunu kadınlarda istihdam oranı \%70,4 düzeyine ulaşmıştır (TÜİK, 2012a). Yükseköğretim mezunu kadınların istihdam oranlarını dikkate aldığımızda Türkiye' de kadınların eğitim seviyesinin yükselmesine bağlı olarak çocuk sayısında ve nüfus artış hızında azalmalar görüleceği söylenebilir.

Eğitim seviyesinin yükselmesinin, çocuk sayısını ve dolayısıyla da nüfus artış hızını nasıl etkileyeceğini belirlemek amacıyla araştırma grubuna kendileri de dâhil olmak üzere ailelerindeki çocuk sayısının kaç olduğu sorulmuş ve ardından da kendi ideallerindeki çocuk sayısının kaç olduğu sorularak karşılaştırma imkânı elde edilmiştir.

Araştırma grubunun, kendileri de dâhil olmak üzere kardeş sayıları Tablo 8'de gösterilmiştir. Tabloda görüldüğü üzere araştırma grubumuzun ailelerinde çocuk sayısı 2 ve 3 çocukta yoğunlaşmıştır. Kardeş sayılarının ortalamalarını (mean) aldığımızda ise karşımıza 3,11 rakamı çıkmaktadır ki bu rakam Başbakanın ailelere tavsiye ettiği rakamın üzerindedir.

\begin{tabular}{|c|c|c|c|}
\hline \multicolumn{4}{|c|}{ Tablo 8: Ailedeki Çocuk Sayısı } \\
\hline & $\mathrm{F}$ & Yüzde \% & Geçerli \% \\
\hline 1 & 18 & 5,3 & 5,3 \\
\hline 2 & 110 & 32,4 & 32,4 \\
\hline 3 & 108 & 31,9 & 31,9 \\
\hline 4 & 52 & 15,3 & 15,3 \\
\hline 5 & 23 & 6,8 & 6,8 \\
\hline 6 ve daha fazla & 28 & 8,3 & 8,3 \\
\hline Toplam & 339 & 100,0 & 100,0 \\
\hline
\end{tabular}

Aşağıda yer alan Tablo 9'da ise araştırma grubunun düşüncelerinde yer alan ideal çocuk sayısına ait rakamlar yer almaktadır. Bu tabloda da yukarıdakine benzer şekilde çocuk sayısı tercihi 2 ve 3 çocukta yoğunlaşmış, ancak 2 çocuk sayısına olan rağbet oldukça 
artmıştır. İşte bu rakam, Başbakanın neden sürekli olarak 3 çocuk vurgusu yaptığını izah etmektedir.

İdeal olduğu düşünülen çocuk sayısının istatistiksel ortalaması (mean) alındığında ise 2,68 rakamı ortaya çıkmaktadır. Bu rakam yukarıda yer alan 3,11 rakamının oldukça gerisindedir. Bununla birlikte eşlerin birlikte çalışması ve çocuk yapmanın getireceği maliyetler sebebiyle de ailelerin düşüncelerindeki ideal çocuk sayısına ulaşamamaları mümkündür. Avrupa Birliği ülkelerine ait istatistik veriler, ailelerdeki mevcut çocuk sayısının ideal olduğu düşünülen çocuk sayısından düşük olduğunu göstermektedir (Daly, 2006).

1988 TAYA verilerine göre, ailede istenen çocuk sayısının eğitim seviyesine göre azaldığg ve erkeklerin kadınlardan daha fazla çocuk istediği tespit edilmiştir. Bir çocuk isteyenlerin oranı sadece $\% 1,98$ 'dir. İki çocuk isteyenlerin oranı $\% 55,92$; üç çocuk isteyenlerin oranı $\% 32,25$; dört ve daha fazla çocuk isteyenlerin oranı ise $\% 9,69$ 'dur. Kır-Kent ayrımında istenen çocuk sayısının farklılaştığı görülmektedir.

1988 TAYA verileyle bizim verilerimiz mukayese edildiğinde istenen çocuk sayısı oranlarında dikkate değer bir farklılaşma olmadığı görülmektedir. Yalnız, bizim verilerimizde erkeklerle kadınlar arasında istenen çocuk sayısı ile ilgili olarak anlamlı bir farklılık bulunamamıştır $(\mathrm{P}=0,073)$. TAYA verileri Türkiye genelini esas aldığına göre, bizim verilerimiz, eğitim seviyesinde meydana gelen yükselmenin ideal çocuk sayısı ile ilgili olarak kadın ve erkekler arasındaki farkı azalttığını ortaya koymaktadır.

\begin{tabular}{|c|c|c|c|}
\hline \multicolumn{4}{|c|}{ Tablo 9: İdeal Olduğu Düşünülen Çocuk Sayısı } \\
\hline & $\mathrm{F}$ & Yüzde $\%$ & Geçerli \% \\
\hline 1 & 8 & 2,4 & 2,4 \\
\hline 2 & 169 & 49,9 & 50,0 \\
\hline 3 & 113 & 33,3 & 33,4 \\
\hline 4 & 31 & 9,1 & 9,2 \\
\hline 5 & 6 & 1,8 & 1,8 \\
\hline 6 ve daha fazla & 11 & 3,2 & 3,3 \\
\hline Cevapsız & 1 &, 3 & \\
\hline Toplam & 339 & 100,0 & \\
\hline
\end{tabular}

Ailelerdeki çocuk sayısını azaltan ve dolaylı olarak da nüfus artış hızını yavaşlatan önemli etkenlerden birisi de evlenme yaşlarındaki yükselmelerdir. 2011 yılı verilerine göre ortalama ilk evlenme yaşı erkeklerde 26,6 ve kadınlarda 23,3 düzeyindedir (TÜİK, 2012b). Bu rakam son 30 yılda yaklaşık olarak 1,5 puan yükselmiştir. Türkiye'de eğitim seviyesinin yükselmesine bağlı olarak bu rakamlarda ilerleyen dönemlerde küçük artışlar olması muhtemeldir. 
Araştırma grubuna kaç yaşında evlenmeyi düşündükleri sorulmuş ve yanıtlar aşağıda Tablo 10'da gösterilmiştir. Araştırma grubunun büyük çoğunluğu 25-27 yaş arasını evlenme yaşı olarak tercih etmektedir. 28-30 yaş arasını tercih edenlerin oranı da oldukça yüksektir. $\mathrm{Bu}$ sonuçlar, araştırma grubunun \%85,8'inin 25-30 yaş aralığında evlenmeyi tercih edeceğini göstermektedir.

Çapraz ilişkide, tercih edilen evlenme yaşı ile cinsiyet arasında anlamlı bir ilişki bulunmuştur. $\mathrm{Bu}$ anlamlı ilişki, kadınların evlenme yaşı olarak geç yaşları tercih etmemelerinden kaynaklanmıştır. 30 yaşın üzerinde evleneceğini belirten \%6,2'lik kesimin sadece \%1,5' ini kadınlar oluşturmuştur.

\begin{tabular}{|l|c|c|c|}
\hline \multicolumn{4}{|c|}{ Tablo 10: Tercih Edilen Evlenme Yaşı } \\
\hline & $\mathrm{F}$ & Yüzde \% & Geçerli \% \\
\hline $21-24$ & 20 & 5,9 & 5,9 \\
\hline $25-27$ & 159 & 46,9 & 47,2 \\
\hline $28-30$ & 130 & 38,4 & 38,6 \\
\hline 31 ve üzeri & 21 & 6,2 & 6,2 \\
\hline Diğer & 7 & 2,1 & 2,1 \\
\hline Cevapsız & 2 &, 6 & \\
\hline Toplam & 339 & 100,0 & \\
\hline
\end{tabular}

Geç yaşta evlenmenin bireysel bir tercih mi olduğu yoksa şartların ortaya çıkardığı bir zorunluluk mu olduğunu ölçmek üzere araştırma grubuna şartları müsait olsa üniversitede okurken evlenmeyi isteyip istemeyecekleri sorulmuş ve sonuçlar aşağıda Tablo 11'de gösterilmiştir.

Araştırma grubu içerisinde şartları müsait olsa erken yaşta evlenmek isteyeceğini belirtenlerin toplam oranı \%20,7 düzeyindedir. Bu grubun dişında kalanlar erken yaşta evlenmeyi ya hiç istememekte $(\% 42,6)$ ya da bu konuda gönülsüz gözükmektedir $(\% 36,7)$.

\begin{tabular}{|l|c|c|c|}
\hline \multicolumn{4}{|c|}{ Tablo 11: Şartlar Müsait Olsa Üniversitede Okurken } \\
Evlenmeyi İsteme Oranları \\
\hline & F & Yüzde \% & Geçerli \% \\
\hline Hiç & 144 & 42,5 & 42,6 \\
\hline Çok az & 64 & 18,9 & 18,9 \\
\hline Biraz & 60 & 17,7 & 17,8 \\
\hline Fazla & 30 & 8,8 & 8,9 \\
\hline Çok fazla & 40 & 11,8 & 11,8 \\
\hline Cevapsız & 1 &, 3 & \\
\hline Toplam & 339 & 100,0 & \\
\hline
\end{tabular}




\section{Evlenilecek Eşte Aranan Özellikler}

Evlilik, oldukça karmaşık bir ilişkiler ağının süzgecinden geçerek ortaya çıkabilen bir olgudur. Evlenmek için kadın ve erkeğin birbirini isteyip kabul etmesi her zaman yeter ve geçerli şart değildir. Bazen iki taraf da birbirini arzulayarak evlenir. Bazen eşlerden birisi arzuludur, diğeri ise aile ve çevre baskısıyla evlenmek zorunda kalmıştır. Bazen toprakların bölünmemesi için, bazen başlık parası için, bazen namus temizlemek için, bazen de güç ve itibar için evlenilir. Bu örnekleri çoğaltmak mümkündür. Bütün bu örneklerin ortak noktası ise, evliliklerin bir takım psikolojik ve sosyal süreçler sonucunda gerçekleştiğidir.

Evliliğin bu karmaşık yapısı ve zaman zaman hiç beklenmedik şekilde gerçekleşmesi nedeniyle Türk toplumunda evlilik bir kısmet olayı olarak görülmüş ve bunu ifade eden pek çok özdeyiş türetilmiştir (Y1lmaz, 2005).

$\mathrm{Bu}$ araştırmanın sonuçlarından da anlaşılabileceği gibi, genç bireyler evliliğin sosyal boyutunun evlilikler üzerindeki etki derecesinin çok fazla farkında değildir. Bu durum zaman zaman hayal kırıklıklarına da yol açmaktadır. Bu makalenin yazıldığı günlerde ulusal yayın yapan bir kanalın ana haber bülteninde, evlilik öncesi yaşanan tartışmalar nedeniyle evlenme niyetinde olan çiftlerin beşte birinin, daha evlenmeden ayrıldıkları bilgisi yer almıştır. İstatistiksel olarak tespit edilmesi oldukça zor olan bu konu ile ilgili haberin kaynağını her ne kadar araştırmamış olsak da, herkesçe bilinen bir gerçeğe işaret etmesi nedeniyle bu haberi burada dile getirmemizin bir sakıncası yoktur.

Evliliğin sosyal yönü, evlilik öncesi ilişkilerde ortaya çıktığı gibi evlilik sonrası ilişkilerde de varlığını sürdürmektedir. Günümüzde yeni evlenen gençlerin farklı bir eve taşınmasının yaygınlaşmasıyla geçmiş zamanlarda sık sık gündeme gelen gelin-kaynana anlaşmazlıkları gibi tartışmaların azalması evliliklerde sosyal ilişkilerin önemini kaybettiği anlamına gelmez. O çatışmalar, aynı çatı altında uzun süre birlikte kalanlar arasındaki psikolojik gerilimden kaynaklanıyordu. Günümüzde ise evlilik öncesinde sevme ve beğenme gibi psikolojik etkenlerle gelişmiş ve sosyal yönü ihmal edilmiş evlilikler, eski dönemdeki psikolojik gerilime neden olan evliliklerden çok daha fazla yıkıcı olabilmektedir. Türkiye'de boşanma patlaması dönemi olarak adlandırabileceğimiz son on yılı bu çerçevede ele almakta fayda vardir.

Günümüzde, evlilik kararlarında bireysel tercihlerin arttığı gözlemlenebilen bir husustur. Aşağıda yer alan Tablo 12 ve Tablo 13'te araştırma grubunun evlenecekleri eşte aradıkları özelliklerle ilgili iki değişkene yer verilmiştir.

Araştırma grubunun \%87,3'lük bölümü evleneceği kişi ile aynı dünya görüşünde olmayı fazla ya da çok fazla tercih edeceklerini belirtmişlerdir (Tablo 12). Aynı dünya görüşünde olmak elbette çok geniş bir kavramdır. Aynı dinden olmak, aynı mezhepten olmak, 
aynı partiyi desteklemek, aynı dindarlık derecesine sahip olmak, aynı ahlaki erdemlere sahip olmak, aynı değer yargılarına sahip olmak vb. şeklinde liste uzatılabilir. Araştırma grubumuz içerisinde evleneceği kişi ile aynı dünya görüşünde olmayı fazla önemsemeyenlerin oranı ise $\% 12,7$ düzeyinde kalmıştır. Bu grubun, evlilikteki sosyal ilişkilerin öneminin çok fazla farkında olmayan grubu temsil ettiğini söyleyebiliriz.

Diğer tabloda ise araştırma grubunun eşlerinin üniversite mezunu olmasını isteme oranlarına yer verilmiştir. Eşlerinin üniversite mezunu olmasını fazla ya da çok fazla isteyenlerin toplam oranı \%56,8 olarak gerçekleşmiştir. Cinsiyete göre gerçekleştirdiğimiz çapraz ilişki tablosunda bu konuda erkeklerle kadınlar arasında oldukça anlamlı bir farklılığın olduğu görülmüştür. Oranları incelediğimizde ise \%56,8'lik oranın \%20,4'ünü erkekler, \%36,4'ünü ise kadınlar oluşturmuştur. Evlilikte erkeğin kadına denk olma şartının arandığı bir geleneğe sahip olan bir toplumda bu oranın kadınlar açısından çok daha yükssek olması beklenirdi. Bu soruya cevap verenlerin çoğunlukla bekâr olduklarını göz önüne alarak, kendileri evlenirken çevrelerinin de yönlendirmesiyle özellikle kadınlar açısından evlenecekleri eşin üniversite mezunu olmasını isteme oranlarının yükseleceği söylenebilir.

\begin{tabular}{|l|c|c|c|}
\hline \multicolumn{4}{|c|}{ Tablo 12: Evleneceği Kişi İle Aynı Dünya Görüşünde Olmayı } \\
İsteme Oranları
\end{tabular}

\begin{tabular}{|l|c|c|c|}
\hline \multicolumn{4}{|c|}{ Tablo 13: Evlenilecek Eşin Üniversite Mezunu Olmasını } \\
\hline & $\mathrm{F}$ & Yüzteme Oranları $\%$ & Geçerli \% \\
\hline Hiç & 38 & 11,2 & 11,2 \\
\hline Çok az & 30 & 8,8 & 8,9 \\
\hline Biraz & 78 & 23,0 & 23,1 \\
\hline Fazla & 68 & 20,1 & 20,1 \\
\hline Çok fazla & 124 & 36,6 & 36,7 \\
\hline Cevapsız & 1 &, 3 & \\
\hline Toplam & 339 & 100,0 & \\
\hline
\end{tabular}




\section{Kadınların Çalışmasına Yönelik Düşüncelerle İlgili Bulgular}

EU-27 ülkelerinde kadınların işgücüne katılım oranı \%62,3 düzeyinde olduğu halde Türkiye'de bu oran \%28,5 gibi görece olarak oldukça düşük bir düzeyde kalmıştır. Kadınların işgücüne katılım oranları bir yandan olumlu anlamda ekonomiye etki ederken diğer yandan da çocuk sayısının azalmasına neden olarak uzun vadede ekonomik kayıplara neden olmaktadır. $\mathrm{Bu}$ nedenle kadınların işgücüne katılım oranlarının tespit edilmesi önem arz etmektedir.

2012 yılı TÜİK verilerine göre yükseköğretim mezunu kadınlarda istihdam oranı \%70,4 düzeyine ulaşmıştır. Yukarıdaki verilerle birlikte değerlendirilecek olursa Türkiye'de eğitim seviyesinin yükselmesine bağlı olarak kadınların işgücüne katılım oranlarında önemli oranda artışlar olacağı söylenebilir.

Aşağıda yer alan Tablo 14 ve Tablo 15'te araştırma grubunun, kadınların çalışması ile ilgili düşüncelerine yer verilmiştir. Araştırma grubu içerisinde kadınların çalışmasını hiç gerekli görmeyenlerin oranı görece olarak oldukça düşük kalmıştır $(\% 6,5)$. Kadınların çalışmasını fazla ya da çok fazla gerekli görenlerin oranı \%61,2 oranında gerçekleşmiştir. Bu oran EU-27 ülkelerindeki kadınların işgücüne katılım oranına oldukça yakındır.

Araştırma grubu içerisinde, kadınların çalışması gerektiği düşüncesine kısmen katılanların oranı ise \%32,3 olarak gerçekleşmiştir. Bu grubu oluşturanların önemli bir bölümünü, kadınların çalışma ortamları ile ilgili çekinceleri olan muhafazakâr düşünceye sahip olanların oluşturduğu söylenebilir.

Cinsiyete göre incelemiş olduğumuz çapraz ilişki tablosunda kadınların çalışması konusunda kadınlarla erkekler arasında oldukça anlamlı bir ilişki olduğu görülmüştür $(\mathrm{P}=0,000)$. Kadınların çalışmasını fazla ya da çok fazla gerekli gören \%61,2'lik kesimin \%41,2'sini kadınlar oluşturmaktadır. Bu oranlar, kadınların gelir getirici işlerde çalışarak kocalarından bağımsız olma konusunda oldukça istekli olduklarını göstermektedir. Eşlerinin çalışması konusunda istekli olan erkeklerin ise bu istekleri genellikle ekonomik sebeplere dayanmaktadir.

Araştırma grubuna çocuğu olan kadınların çalışması ile ilgili düşünceleri de ayrıca sorulmuştur. Çocuğu da olsa bir kadının çalışması gerektiğini fazla ya da çok fazla gerekli görenlerin toplam oranı \%38,5 olarak gerçekleşmiştir. Bu oran, çocuğu olmayan kadınların çalışması ile ilgili sorumuza göre \%22,7 gerileme göstermiştir. Bu durum, çocuğu olan kadınların çalışması konusunda bir çekince olduğunu göstermektedir. O halde buradan çıkaracağımız sonuç, çalışan kadınların ekonomik kayıplarını göz önüne alarak çocuk doğurmayı erteleyecekleri şeklinde olacaktır.

Cinsiyete göre incelemiş olduğumuz çapraz ilişki tablosunda ise çocuğu olan kadının da çalışması gerektiği konusunda kadınlarla erkekler arasındaki anlamlı farklılaşmanın devam ettiği görülmektedir. Ancak burada ilginç olan sonuç çocuğu olan kadının çalışması 
konusunda erkeklerle kadınlar arasındaki farkın kadınlar lehine aşırı derecede artmış olmasıdır. Diğer bir ifadeyle çocuklu kadının çalışması konusunda erkekler daha isteksiz davranırken, kadınlar bu konudaki isteklerini kaybetmemektedir.

\begin{tabular}{|l|c|c|c|}
\hline \multicolumn{4}{|c|}{ Tablo 14: Kadınların Çalısmasının Gerekli Olduğu Düşünme } \\
& $\mathrm{F}$ & Yüzde $\%$ & Geçerli \% \\
\hline Hiç & 22 & 6,5 & 6,5 \\
\hline Çok az & 27 & 8,0 & 8,0 \\
\hline Biraz & 82 & 24,2 & 24,3 \\
\hline Fazla & 92 & 27,1 & 27,2 \\
\hline Çok fazla & 115 & 33,9 & 34,0 \\
\hline Cevapsırı & 1 &, 3 & \\
\hline Toplam & 339 & 100,0 & \\
\hline
\end{tabular}

\begin{tabular}{|l|c|c|c|}
\hline \multicolumn{4}{|c|}{ Tablo 15: Çocuğu Olan Kadımın da Çalışması Gerektiğini } \\
Düşünme Oranları \\
\hline & F & Yüzde \% & Geçerli \% \\
\hline Hiç & 48 & 14,2 & 14,2 \\
\hline Çok az & 71 & 20,9 & 21,0 \\
\hline Biraz & 89 & 26,3 & 26,3 \\
\hline Fazla & 70 & 20,6 & 20,7 \\
\hline Çok fazla & 60 & 17,7 & 17,8 \\
\hline Cevapsız & 1 &, 3 & \\
\hline Toplam & 339 & 100,0 & \\
\hline
\end{tabular}

\section{Ebeveyn ve Eş Ebeveyni İle Olan İlişkilere Yönelik Bulgular}

Yukarıda da belirttiğimiz gibi, evlilik sosyal yönü psikolojik yönüne ağır basan bir kurumdur. Evli olan eşlerin kendi ebeveynleriyle ya da eşlerinin ebeveynleriyle olan ilişkilerinde de geçmişe kıyasla önemli değişimler yaşanmıştır. Bu değişimlerin temelinde ise kentleşmenin yer aldığını söylemeliyiz. Çünkü birden fazla kuşağın bir arada bulunması, birbiriyle kan bağıyla bağlı birden fazla ailenin bir arada bulunması gibi özellikler daha çok kırsal bölgelere has özelliklerdir. A. Duben (1984) ve A. Kurt'un (1998) araştırmaları Osmanlı döneminin şehir hayatında da çekirdek ailenin ön planda olduğunu, hanehalkı sayısı ve çocuk sayısı gibi rakamların da günümüzden ayırt edilebilir bir farklılığa sahip olmadığını ortaya koymuştur. 
Günümüzde nüfusun dörtte birden fazlasının şehirlerde yaşamaya başlamasıyla birlikte hanehalkı sayısında düşüşler olmuştur. Ancak, yaşlı bireyler köylerinden tamamen ayrılma konusunda fazla istekli değildir. Kırsal bölgelerde ağır kış şartları nedeniyle kış aylarını şehirdeki çocuklarının yanında kalorifer ya da kombi ile ısınan evlerde geçiren yaşlılar, baharla birlikte soluğu köylerinde almaktadır. Bu anlamda, çocuklarıyla uzun vadeli birlikte olma konusunda yaşlılar da fazla istekli değildir.

Şehir hayatında her iki eşin de çalışması çocukların bakımı sorununu gündeme getirmektedir. $\mathrm{Bu}$ durumdaki eşler için, kendi ebeveynleri çocuklarını güvenle emanet edebilecekleri güvenli birer bakıcıya dönüşmektedir. Bütün bunların dışında bir de yaşlı annebabanın bakıma muhtaç olma durumu vardır. Araştırma grubunun bu konudaki düşünceleri ile ilgili veriler Tablo 16 ve Tablo 17' de yer almıştır.

Yaşlı anne-babaya bakma konusunda istekli olma oranları Tablo 16" da gösterilmiştir. Ebeveynine bakma konusunda istekli olanların toplam oranı \%88,8 olarak ölçülmüştür. Bu konuda fazla istekli olmayanların oranı \%3,8 ve hiç istekli olmayanların oranı da \% 7,4 olarak ölçülmüştür. $\mathrm{Bu}$ son grubun, genel olarak ebeveyni ile anlaşamayan kişilerden oluştuğu düşünülebilir.

Yaşlı anne-babaya bakma konusunda istekli olma oranları ile ilgili olarak yapmış olduğumuz çapraz ilişki değerlendirmesinde cinsiyete göre arada anlamlı bir farklılık olduğu görülmüştür. Buna göre, erkeklerde yaşlı anne-babaya bakma konusundaki istek oranı azalırken kadınlarda bu oranın erkeklere oranla daha yüksek olduğu görülmüştür.

Araştırma grubuna yöneltilen sorulardan birisi de, eşlerinin ebeveynleri ile birlikte yaşamayı ne ölçüde onayladıkları ile ilgilidir (Tablo 17). Araştırma grubunun üçte birinden fazlası $(\% 36,6)$, eşinin ebeveyni ile birlikte yaşamayı hiç istemediğini belirtmiştir. Eşinin ebeveyni ile birlikte yaşama konusunda istekli olacağını belirtenlerin oranı ise \%15,4 gibi görece olarak düşük bir rakamda kalmıştır. Bu konuda fazla istekli olmayan, ancak birlikte yaşamaları durumunda fazla sorun çıkarmayacakları anlaşılanların toplam oranı ise \%48,1 düzeyindedir.

Eş ebeveyni ile birlikte yaşama konusunda cinsiyete göre yapmış olduğumuz çapraz ilişki incelemesinde anlamlı bir farklılık bulunamamıştır. Dolayısıyla bu konuda kadın ve erkeklerin benzer düşüncelere sahip olduğu söylenebilir.

\begin{tabular}{|l|c|c|c|}
\hline \multicolumn{4}{|c|}{ Tablo 16: Yaşıı Anne-Babaya Bakma Konusunda İstekli Olma } \\
& Oranları & Yüzde \% & Geçerli \% \\
\hline & 25 & 7,4 & 7,4 \\
\hline Hiç & 2 &, 6 &, 6 \\
\hline Çok az & 11 & 3,2 & 3,2 \\
\hline Biraz & 14 & 4,1 & 4,1 \\
\hline Fazla & 287 & 84,7 & 84,7 \\
\hline Çok fazla & 339 & 100,0 & 100,0 \\
\hline Toplam & & & \\
\hline
\end{tabular}




\begin{tabular}{|l|c|c|c|}
\hline \multicolumn{4}{|c|}{ Tablo 17: Eş Ebeveyni İle Birlikte Yaşamayı Onaylama } \\
Oranları \\
\hline & F & Yüzde \% & Geçerli \% \\
\hline Hiç & 124 & 36,6 & 36,6 \\
\hline Çok az & 69 & 20,4 & 20,4 \\
\hline Biraz & 94 & 27,7 & 27,7 \\
\hline Fazla & 28 & 8,3 & 8,3 \\
\hline Çok fazla & 24 & 7,1 & 7,1 \\
\hline Toplam & 339 & 100,0 & 100,0 \\
\hline
\end{tabular}

\section{Sonuç}

Araştırma sonucunda, üniversite öğrencilerinin evlilik ve aile ile ilgili görüşlerinden yola çıkılarak eğitim seviyesinde meydana gelen değişimin, geleneksel aile modellerinden ne ölçüde uzaklaşmaya neden olacağı ile ilgili şu kanaatlere varılmıştır:

Araştırma grubunun \%13’ü evlilik kararı verirken ailesinin kendisine karışmayacağını belirtmiştir. \%57,5'i ise kararı kendisinin vereceğini ancak ailesine de danışacağını söylemiştir. Bu oranlara bakarak Türkiye'de ilerleyen zamanlarda eğitim seviyesinin yükselmesine paralel olarak evlilik kararlarında bireysel tercihlerin daha fazla ön plana çıkacağı sonucuna ulaşılmıştır.

Araştırma grubunun tercih ettiği evlenme yöntemi ile ilgili bulgular, evlilik kararlarında bireysel tercihlerin arttığını ve erkek çocuğu olan annelerin, çocukları için kız baktığı geleneksel modelden uzaklaşıldığını göstermiştir. Geleneksel ailede yaygın olan "aile ortamında tanışarak evlenme" modelini benimseyen gençlerin oranı görece olarak düşük kalmıştır $(\% 10,4)$.

Tercih edilen evlenme yöntemi cinsiyete göre farklılaşmaktadır. Duygusal bir arkadaşlıktan sonra evlenmeyi isteyenlerin oranı kızlarda daha yüksek çıkmıştır. Bu sonuç, geleneksel ailede kızların nişanlılarıyla bile konuşamadıkları dönemlerin artık geride kaldığını göstermektedir. Eğitim seviyesi yükselen kızlar, artık evlerinde oturarak kendilerine görücü gelmesini fazla tasvip etmemektedir. Aile ortamında tanışarak evlenmeyi benimseme oranı ise erkeklerde daha yüksek çıkmıştır.

Günümüz ailesini geçmişten farklı kılan en önemli özelliklerden birisi de evliliklerin geciktirilmesidir. Avrupa'da olduğu gibi Türkiye' de de evlilik yaşı son birkaç on yılda önemli oranda yükselmiştir. Evlenme yaşının yükselmesinin doğal sonucu olarak da kadınlarda doğurganlık oranları düşmekte ve ailelerdeki çocuk sayısı azalmaktadır. TÜİK verilerine göre 1985 yılında ortalama ilk evlenme yaşı erkeklerde 25,5 ve kadınlarda ise 21,8 iken bu rakamlar düzenli olarak yükselerek 2005 yılında erkeklerde 27,5 ve kadınlarda 23,6' ya 
yükselmiştir. Araştırma grubumuzda da 25-30 yaş aralığında evlenmeyi tercih etme oranı oldukça yüksek çıkmıştır $(\% 85,8)$.

Araştırma grubumuz dinî nikâhı gerekli görüp görmedikleri ile ilgili sorumuza büyük oranda gerekli gördükleri şeklinde cevap vermişlerdir (\%78,4). Bizim 2007 yılında yaptığımız bir araştırmada bu oran \% 78,9 iken 1988 TAYA verilerine göre dinî nikâhın en az görüldügüu Batı Anadolu bölgesinde bu oran \% 84,80 olarak gerçekleşmiştir. Güney Anadolu, İç Anadolu, Karadeniz, Doğu ve Güneydoğu Anadolu bölgelerinin tamamında ise dini nikah oranları \% 90'ların üzerinde ölçülmüştür. Bu sonuçlar, dinî nikâhın toplum genelinde genel bir kabul gördüğünü, ancak bu genel kabulün son yıllarda eğitim seviyesinden bağımsız olarak azalmaya başladığını göstermektedir.

Araştırma grubumuz, dini nikâh yaptırmayı büyük ölçüde gerekli görse de resmi nikâh yapılmadan böyle bir nikâh yapmanın sakıncalarının da bilincindedir. Araştırma grubumuzda dini nikâh yaptırmakta hiçbir sakınca görmeyenlerin oranı $(\% 8,9)$ görece olarak oldukça düşük kalmıştır.

Nikâhsız birlikte yaşama olgusu toplumda her ne kadar artma eğilimi gösterse de tespit edilemeyenler istisna edildiğinde oldukça düşük rakamlar ortaya çıkmaktadır. Nikâhsız birlikte yaşamayı onaylama oranları ise bu rakamların oldukça üzerindedir. Araştırma grubumuzda nikâhsız birlikte yaşamayı hiç onaylamayanların oranı $\% 77$ olarak ölçülmüştür. Bunun dışında kalan \%23'lük bir orana sahip kesimin ise az ya da çok nikâhsız birlikte yaşamayı onayladıkları anlaşılmaktadır. Ancak, örneklem grubumuzun bekâr ve çok genç olmaları dikkate alınarak, ilerleyen yıllarda bu rakamlarda düşüşler görülebileceği vurgulanmıştır.

Dini nikâh konusundaki rakamlar dikkate alındığında, Batı'da gittikçe yaygınlaşmaya başlayan partnerlik ya da evlilik dışı beraberlik gibi yeni aile anlayışlarının, Türkiye' de daha çok dini nikâh şemsiyesi altında devam edeceği vurgusu yapılmıştır.

Eğitim seviyesinin yükselmesine bağlı olarak Türkiye' de akraba evliliklerinde azalma olup olmayacağını belirlemek üzere araştırma grubuna akraba evliliklerini onaylama dereceleri de sorulmuştur. Akraba evliliğini hiç onaylamayanların oranı $(\% 63,7)$ dikkate alındığında akraba evlilikleri konusunda geleneksel anlayışların kısmen devam edeceği anlaşılmaktadır.

Türkiye' nin Avrupa Birliği ile müzakere sürecinde olması ve bazı birlik ülkelerinde eşcinsel evliliklerin serbest olması nedeniyle, Türkiye'de zaman zaman gündeme gelen eşcinsel evlilikler konusu da incelenmiştir. Araştırma grubunun \%20,9'u, eşcinsel evliliklerin kendisini hiç rahatsız etmeyeceğini belirtmiştir. Eşcinsel evliliklerin, kendisini fazla ya da çok fazla rahatsız edeceğini belirtenlerin toplam oranı ise \%65,5 düzeyindedir. Geriye kalan grup ise, eşcinsel evliliklerden kısmî rahatsızlık duyanları temsil etmektedir. Bu konuda geçmiş dönemdeki rakamları bilmesek de verdiğimiz rakamlar aile ile ilgili muhafazakâr anlayıştan uzaklaşma olacağını göstermektedir. 
Eğitim seviyesinin yükselmesinin, çocuk sayısını ve dolayısıyla da nüfus artış hızını nasıl etkileyeceğini belirlemek amacıyla araştırma grubuna kendileri de dâhil olmak üzere ailelerindeki çocuk sayısının kaç olduğu sorulmuş ve ardından da kendi ideallerindeki çocuk sayısının kaç olduğu sorularak karşılaştırma imkânı elde edilmiştir. Araştırmadan elde edilen sonuçlar, araştırma grubunun ideallerinde olan çocuk sayısının kendi kardeş sayılarından düşük olduğunu göstermiştir. Bu da ilerleyen yıllarda eğitim seviyesinin yükselmesine bağlı olarak ortalama çocuk sayısında düşüşler görüleceği sonucuna ulaşmamıza yol açmıştır.

Araştırma grubunun, kadınların çalışması ile ilgili düşünceleri de incelenmiştir. Kadınların çalışması anne olma yaşının ilerlemesine ve çocuk sayısının azalmasına neden olan önemli bir etkendir. Araştırma grubu içerisinde kadınların çalışmasını hiç gerekli görmeyenlerin oranı görece olarak oldukça düşük kalmıştır (\%6,5). Kadınların çalışmasını fazla ya da çok fazla gerekli görenlerin oranı \%61,2 oranında gerçekleşmiştir. Bu oran EU-27 ülkelerindeki kadınların işgücüne katılım oranına oldukça yakındır. Araştırma grubu içerisinde, kadınların çalışması gerektiği düşüncesine kısmen katılanların oranı ise \%32,3 olarak gerçekleşmiştir. Bu grubu oluşturanların önemli bir bölümünü, kadınların çalışma ortamları ile ilgili çekinceleri olan muhafazakâr düşünceye sahip olanların oluşturduğu söylenebilir. Bu sonuçlar eğitim seviyesinin yükselmesine bağlı olarak kadınların işgücüne katılım oranlarının yükseleceği ve bu ailelerde ortalama çocuk sayısının düşeceğini göstermektedir.

Cinsiyetlere göre incelendiğinde ise kadınların çalışması gerektiği düşüncesi kadınlarda oldukça yükselmiştir. Bu oranlar, kadınların gelir getirici işlerde çalışarak kocalarından bağımsız olma konusunda oldukça istekli olduklarını göstermektedir. Bu da geleneksel aile modelindeki, erkeğin çalıştığı kadının ise ev işlerine ve çocuklarına baktığı modelden uzaklaşmalar olacağını göstermektedir.

Yaşlı anne-babaya bakma konusunda istekli olma oranları oldukça yüksek bulunmuştur. Ebeveynine bakma konusunda istekli olanların toplam oranı \%88,8 olarak ölçülmüştür. Bu konuda fazla istekli olmayanların oranı \%3,8 ve hiç istekli olmayanların oranı da \%7,4 olarak ölçülmüştür.

Araştırma grubuna yöneltilen sorulardan birisi de, eşlerinin ebeveynleri ile birlikte yaşamayı ne ölçüde onayladıkları ile ilgilidir. Araştırma grubunun üçte birinden fazlası $(\% 36,6)$, eşinin ebeveyni ile birlikte yaşamayı hiç istemediğini belirtmiştir. Eşinin ebeveyni ile birlikte yaşama konusunda istekli olacağını belirtenlerin oranı ise \%15,4 gibi görece olarak düşük bir rakamda kalmıştır. Geçmiş dönemlerde eş ebeveyni ile birlikte yaşama günümüze göre daha yaygın olsa da gelin-kaynana tartışmalarının türkülere kadar konu olması nedeniyle o dönemde de bunu tasvip etme oranlarının düşük olduğu söylenebilir.

Burada yer alan sonuçlar, araştırma hipotezlerinin büyük oranda doğrulandığını göstermektedir. 


\section{Kaynaklar}

Akdoğan, Ali (2004). Sosyal Değişme ve Din. İstanbul: Rağbet Yayınları.

Akgül, Mehmet (2002). Türkiye'de Din ve Değişim. İstanbul: Ötüken Yayınları.

Cebeci, Dilaver (1993). Tanzimat ve Türk Ailesi. İstanbul: Ötüken Neşriyat.

Daly, Mary (2006). Changing Family Life In Europe: Significance for State and Family.

European Societies, 7(3), DOI: 10.1080/14616690500194001

Duben, Alan (1984). “19. ve 20. Yüzy1l Osmanl1-Türk Aile ve Hane Yapıları”, Türkiye'de

Ailenin Değişimi. Ankara: Maya Matbaacılık ve Yayıncılık.

Duben, Alan - BEHAR, Cem (1996). İstanbul haneleri: evlilik, aile ve doğurganlık: 1880-

1940, İstanbul: İletişim yayınları.

EUROSTAT (2012a). Active Ageing and Solidarity Between Generations, 2012 edition.

EUROSTAT (2012b). Basic Figures on The EU, Summer 2012 edition.

Haviland, William A. ve diğ. (2008). Kültürel Antropoloji. Çev. İnan Deniz-Erguvan Sarığlu. İstanbul: Kaknüs Yayınları.

KARAMAN, Hayrettin (1996). Mukayeseli İslam Hukuku C.1-3, İstanbul: Nesil Yayınları.

Kaya, Erol (2003). Kentleşme ve Kentlileşme, İstanbul: İlke Yayıncılık.

Kurt, Abdurrahman (1998). Bursa Sicillerine Göre Osmanlı Ailesi. Bursa: Uludağ Üniversitesi Basımevi.

Ortaylı, İlber (2000). Osmanlı Toplumunda Aile, İstanbul: Pan Yayınları.

Roof, Wade Clark (1993). A generation of seekers: The spiritual journeys of the baby boom generation. New York: Harper Sanfrancisco.

Şentürk, Recep (2004). Yeni Din Sosyolojileri, İstanbul: Gelenek Yayıncılık.

Tezcan, S.-Coşkun, Y. (2004). Türkiye'de 20. Yüzyılın Son Çeyreğinde Kadınlarda İlk Evlenme Yaşı Değişimi ve Günümüz Evlilik Özellikleri, Nüfusbilim Dergisi/Turkish Journal of Population Studies, 2004, 26, 15-34, http://www.hips.hacettepe.edu.tr/nbd_cilt26/tezcan_coskun.pdf, 20.06.2012. 
Türk Aile Yapısı Araştırması [TAYA](1993), Haz. Atalay, B.-Kontaş M. Y.-Beyazıt, S.-

Madenoğlu K., Ankara: Devlet Planlama Teşkilatı Araştırma Dairesi.

TÜİK, İstatistik Göstergeler 1923-2006, www.tuik.gov.tr

TÜİK (2006). Aile Yapısı Araştırması, www.tuik.gov.tr

TÜİK (2008). TÜİK Haber Bülteni, Sayı: 104, 26 Haziran 2008, www.tuik.gov.tr

TÜIKK (2012a). TÜİK Haber Bülteni, Sayı: 10775, 15 Mart 2012, www.tuik.gov.tr

TÜİK (2012b). TÜİK Haber Bülteni, Sayı: 10844, 15 Haziran 2012, www.tuik.gov.tr

TÜİK (2012c). TÜİK Haber Bülteni, Sayı: 10736, 27 Ocak 2012, www.tuik.gov.tr

Türkdoğan, Orhan (2002). Türk Toplum Yapısı. İstanbul: Çamlıca Yayınları

Y1lmaz, Sinan (2005). Evlilikte Kader ve Kısmet. İstanbul: Nesil Yayınları.

- (2008). Türk Ailesinin Dönüşümü ve Din. İstanbul: Basılmamış doktora tezi.

--------- (2010). Türk Aile Örüntülerindeki Değişimlerin Açıklanmasında Farklı Sosyoloji Teorilerinin Faydalı Olabilecek Yönleri, Toplum Bilimleri Dergisi, 4(8), 67-82. 